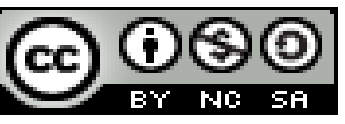

\title{
Estudio comparativo entre el uso de la Seda 3/0 y la síntesis adhesiva con Cianoacrilato en cirugía de terceros molares retenidos
}

Comparative study between the use of 3/0 Silk and cyanoacrylate adhesive in surgery of retained wisdom teeth.

\section{Estudo comparativo entre o uso da seda 3/0 e a síntese adesiva com cianoacrilato em cirurgia de terceiros molares retenidos}




\section{Resumen.}

Objetivo: Comparar la efectividad en los procesos de cicatrización de las heridas quirúrgicas, de los materiales para síntesis entre el hilo de Seda 3/0 y el adhesivo tisular de Cianoacrilato. Materiales y Metodos: Se realizó en 35 pacientes que presentaron las piezas dentales No. 38 y 48 retenidas, mesioangulares, clase II y posición B, una vez que se llevaron a cabo las intervenciones quirúrgicas para la extracción de las piezas dentales retenidas, se realizó la síntesis de los colgajos de cada paciente utilizando sutura adhesiva de Cianoacrilato en el lado derecho e hilo de seda trenzada 3/0 en el lado izquierdo. Se realizó la evolución postquirúrgica del área operada en ambos lados al tercer, quinto y séptimo días; tomando en cuenta la acumulación de placa bacteriana, inflamación, dehiscencia e infección, los resultados fueron tabulados y procesados por plantillas de datos de Microsoft Excel. Resultados: Las heridas de la sutura adhesiva de con Cianoacrilato, como medio de síntesis de colgajos mucoperiósticos, disminuyó el tiempo operatorio en su colocación, no necesitó ser removido, protegió la herida del depósito de placa bacteriana, así como también disminuyó la presencia de inflamación en la zona operada y la dehiscencia. Conclusiones: Existe una dehiscencia considerablemente menor en la herida suturada con Cianoacrilato en relación con la Seda 3/0, en las cuales la mayoría de pacientes si la presentaba.

Palabras clave: Seda 3/0; cianoacrilato; heridas quirúrgicas. 


\section{Abstract.}

Objective: Compare the effectiveness of surgical wound healing processes between 3/0 Silk thread and cyanoacrylate tissue adhesive. Materials and Methods: A 35 patients sample with retained, mesio-angular, class II and B-position of teeth No. 38 and 48 was used. Once surgical procedures were performed for extraction of retained dental teeth, we performed the synthesis of flaps on each patient using cyanoacrylate adhesive suture on the right side and 3/0 braided silk thread on the left side. Postoperative evolution controls on both sides was performed on the third, fifth and seventh day; Considering plaque accumulation, inflammation, dehiscence and infection, results were processed by Microsoft Excel data templates. Results: Wounds with cyanoacrylate adhesive, as mucoperiosteal flap synthesis, requiered lees placement time, had no need to be removed, protected the wound from bacterial plaque deposits, as well as decreased swelling in the operated area and dehiscence. Conclusions: There is a considerably lower dehiscence in the wound sutured with Cyanoacrylate in relation to Silk 3/0.

Key Words: Silk 3/0; cyanoacrylate; surgical wounds. 


\section{Resumo.}

Objetivo: Comparar a eficácia no processo de cicatrização das feridas cirúrgicas, dos materiais para síntese, entre fio de seda 3/0 e o adesivo tissular cianoacrilato. Materiais e Métodos: Realizou-se em 35 pacientes que apresentaram dentes No. 3.8 e 4.8 retenidos, mesioangulares, classe II posição B, depois das intervenções cirúrgicas para enucleação dos dente retenidos, realizou-se síntese dos retalhos de cada paciente utilizando sutura adesiva de cianoacrilato no lado direito e fio de seda trançada 3/0 no lado esquerdo. Realizou-se evolução post-cirúrgica na área operada nos dois lados ao terceiro, quinto e sétimo dias; valorou-se acumulação de placa bacteriana, inflamação, deiscência e infecção, os resultados foram tabulados e processados por modelos de dados do software Microsoft Excel. Resultados: Nas feridas que utilizaram como meio de síntese de retalhos mucoperiósticos sutura adesiva de cianoacrilato, diminuíra o tempo operatório na colocação, não precisou ser removido, protegeu a ferida do deposito de placa bacteriana, também diminuiu presença de inflamação e deiscência na zona operada. Conclusões: Existiu deiscência consideravelmente menor nas feridas suturadas com cianoacrilato em relação com seda 3/0, nas quais o paciente a apresentaram.

Palavras Chave: Seda 3/0; cianoacrilato; feridas cirúrgicas. 


\section{Introduccion.}

Uno de los tiempos dentro de la cirugía de terceros molares retenidos es la síntesis que consiste en unir los bordes de la herida y asegurar de esta forma el cierre por primera intención. Se han utilizado para este propósito muchos materiales de sutura.

Los materiales de los que están constituidos los hilos de sutura se distinguen en reabsorbibles y no reabsorbibles. Los hilos reabsorbibles son utilizados para suturas submucosas y subcutáneas o localizadas en zonas de difícil acceso para la remoción de puntos. (1)

Los hilos no reabsorbibles son utilizados porque presentan buenas propiedades mecánicas, elasticidad elevada, flexibilidad y facilidad de uso; pueden ser subdivididos en naturales o sintéticos. Entre los naturales, el más utilizado en la actualidad es la seda. (1)

El colgajo cicatrizará en 2 o 3 semanas, siempre que sea ligado con suturas tensas, y se logre una perfecta adaptación a los tejidos subyacentes. (2)

Es indudable que la tecnología sigue avanzando cada día más, creando nuevas técnicas y materiales que ayudan a las ciencias médicas y dentro de ésta a la Odontología

Entre estos materiales existe el cianoacrilato que es un adhesivo tisular a base de monómeros cianoacrílicos que polimerizan en contacto con las superficies húmedas creado para el sello de heridas quirúrgicas o traumáticas recientes y se puede utilizar en cirugía para la síntesis de colgajos mucoperiósticos en lugar de la sutura convencional. $(3,4)$

El cianoacrilato de n-butilo tiene materiales biocompatibles y algunos inhibidores que fragua en presencia de fluidos biológicos, los que actúan como verdaderos iniciadores de la reacción 
química, adhiriéndose fuertemente a los tejidos. Este proceso de fraguado que por su tipo es una reacción de polimerización, presumiblemente del tipo aniónico, toma lugar de forma paralela con otra no menos importante que consiste en la formación de uniones químicas entre grupos funcionales de la estructura cianoacrílica y las proteínas. Esta unión es la razón de la fuerte adhesividad y el marcado carácter hemostático que presentan los cianoacrilatos frente a las lesiones de los tejidos vivos. Por otra parte las estructuras cianoacrílicas son fuertemente bactericidas, lo que unido al ya demostrado carácter biodegradable de sus polímeros reúnen una serie de propiedades altamente favorables para utilizarlos como adhesivos biológicos, con carácter hemostático, con poder bactericida y sin necesidad de remoción posterior. (5)

Algunos estudios han demostrado el carácter antimicrobiano del cianoacrilato frente a microorganismos Gram+, no observándose el mismo efecto para los Gram-, lo que puede indicar que el fenómeno de bacteriostásis que presentan estos productos, pudiera estar dado por la acción combinada de aquellos microorganismos que forman parte de la microbiota del cuerpo humano, en el proceso de degradación de la molécula de cianoacrilato, generando cantidades de formaldehído altamente tóxicos para estas especies. (6)

Sobre el carácter hemostático, descubierto después del uso como adhesivo, se acepta una explicación basada en considerar la reacción entre la estructura cianoacrílica y las proteínas presentes en la sangre. Estas uniones entre las macromoléculas del adhesivo que se forman durante la reacción de polimerización con la hemoglobina y otras proteínas presentes, conforman un enrejado tridimensional que 'atrapa' los líquidos favoreciendo notablemente el proceso posterior de coagulación. 
El cianoacrilato tiene la propiedad de ser de fácil manejo para el cirujano puesto que no requiere mucho entrenamiento previo, además es biocompatible con los tejidos orales, es bacteriostático, hemostático, no necesita una segunda sesión para ser removido. $(7,8,9)$

El presente estudio tiene el propósito de buscar y conocer nuevas técnicas de cierre de heridas que ayuden al proceso normal de cicatrización.

\section{Materiales y metodos.}

Este es un tipo de estudio descriptivo longitudinal. Es un tipo de estudio descriptivo ya que evalúa y mide los resultados de dos técnicas de síntesis en tejidos mucosos y es un diseño no experimental longitudinal porque recolecta datos en varios momentos para observar resultados. En ésta investigación el área de estudio fueron las clínicas de Cirugía Oral de la Facultad de Odontología de la Universidad Central del Ecuador y clínicas Privadas, son lugares donde se presta servicio de cirugía oral especializados en la extracción de terceros molares retenidos.

En cada paciente se realizó una incisión de $20 \mathrm{~mm}$ a cada lado, pero en el tiempo quirúrgico de síntesis, en el lado izquierdo de la boca se utilizó hilo de seda 3/0 y en el lado derecho se selló la herida con sutura adhesiva de cianoacrilato.

En este estudio se aplicó una técnica de sutura de puntos sueltos, es decir, independientes, que consiste en traspasar los dos bordes de la incisión con sutura de hilo de seda 3/0 aguja, con un doble nudo inicial y un simple. Se realizó dos puntos sueltos. 
El cianoacrilato es un líquido, no viscoso, de color violeta, su presentación comercial es un frasco de $5 \mathrm{ml}$. Viene con ámpulas plásticas que se utilizan individualmente con cada paciente, las cuales se llenan con el material mencionado.

Se afrontan los bordes de la incisión presionándolos entre sí pero sin tensión, se limpia la zona con torundas de gasa para detener el sangrado, luego se aplica el cianoacrilato en una cantidad de $0.1 \mathrm{ml}$ que corresponde a 3 o 4 gotas en una capa muy fina del mismo, deslizando el cuello de la ámpula plástica sobre los bordes de la incisión. Se aplica el pegamento en superficie y no en la pared cruenta de la herida, ya que actuaría de cuerpo extraño y haría de barrera para el proceso de curación. Los excesos del material provocan la formación de una capa de polímero que se desprende fácilmente por roce mecánico. Se mantiene la herida unida por 1 a 2 minutos. $(10,5)$

En esta investigación se evaluaron cada una de variables para darles valores numéricos y se describieron para poder analizarlos individualmente; se observaron los resultados de la utilización de la sutura adhesiva con cianoacrilato y de la sutura convencional con seda $3 / 0$ en cada paciente y se compararon los resultados y los datos para sintetizar las conclusiones y recomendaciones que arrojó la investigación.

Se seleccionaron 35 pacientes con 70 incisiones, de ambos sexos, 23 de sexo femenino y 12 del masculino, entre 14 a 27 años de edad con los siguientes criterios de inclusión:

Terceros molares retenidos en posición B, clase II. Mesioangulares $\left(\right.$ Foto $\left.\boldsymbol{N}^{\circ} \mathbf{1}\right)$

Personas 14 a 30 años de edad de ambos sexos

Personas en buen estado de salud general

Personas sin incapacidad mental y trastornos psíquicos severos 
Personas que dieron su consentimiento por escrito para participar en el estudio, en el caso de ser menores de edad, el consentimiento fue dado por el representante legal.

Los criterios de exclusión fueron los siguientes:

Terceros molares retenidos en posiciones horizontales, verticales, distoangulares, invertidos $\mathrm{y}$ transversos

Terceros molares retenidos de Clase I y Clase III

Terceros molares retenidos en posición A y B

Se excluyen a los pacientes que presenten enfermedades sistémicas

Pacientes inmunodeprimidos

Pacientes con patologías regionales de la zona retromolar como pericoronaritis, problemas gingivales, etc.

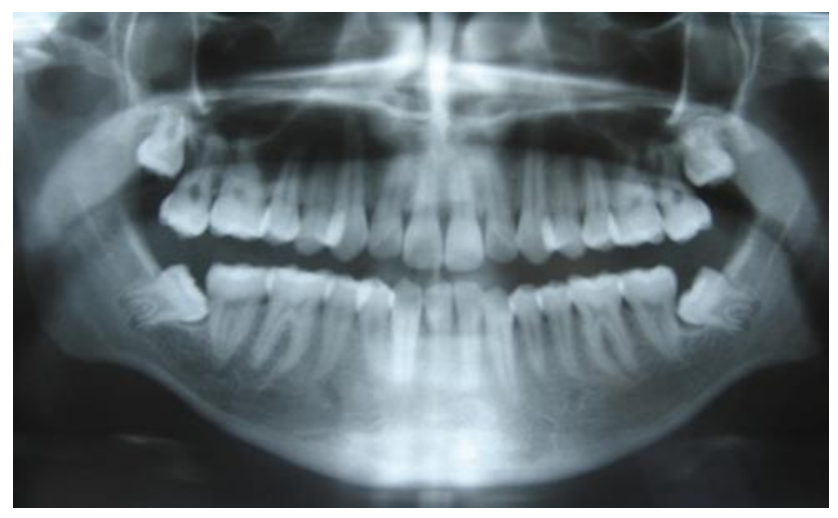

Foto $N^{\circ}$ 1.- Los terceros molares inferiores que se escogieron para la realización de ésta tesis se encuentran en posición mesio-angular para todos los pacientes 


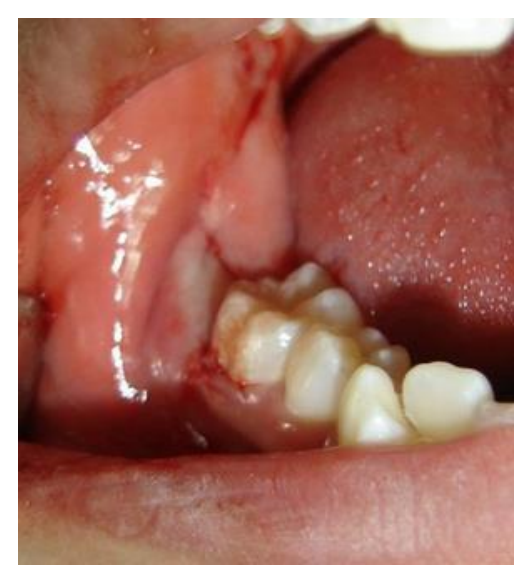

Foto $N^{\circ}$ 2.- La incisión que se utilizó fue una lineal para el lado derecho e izquierdo

En este estudio se aplicó una técnica de sutura de puntos sueltos, es decir, independientes, que consiste en traspasar los dos bordes de la incisión con sutura de hilo de seda 3/0 aguja, con un doble nudo inicial y un simple. Se realizó dos puntos sueltos.

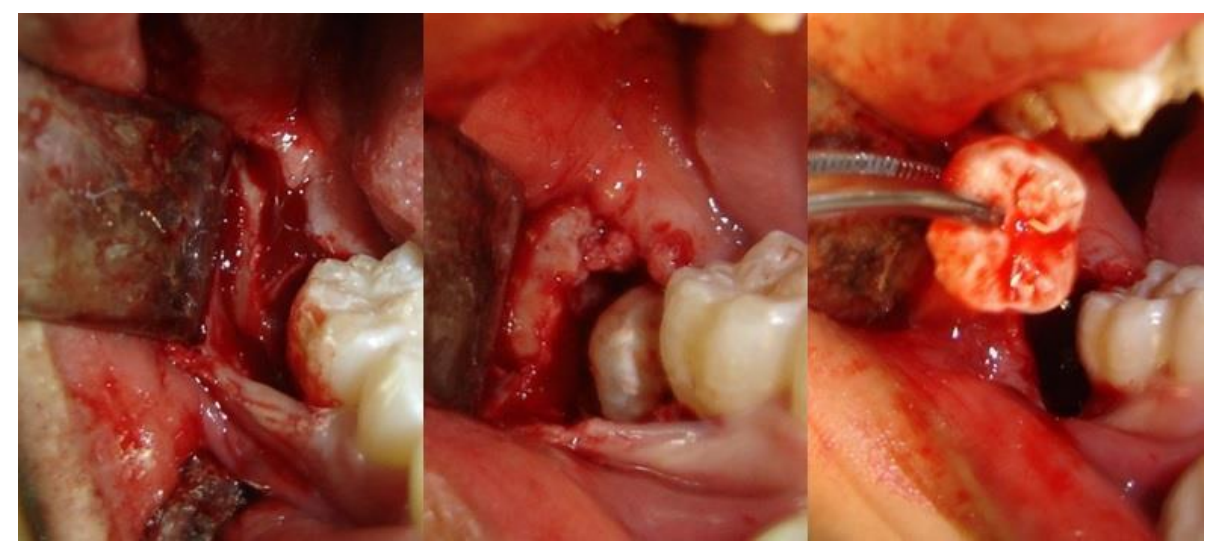

Foto $N^{\circ}$ 3.- Levantamiento de colgajo, Osteotomía, En la mayoría de pacientes se realizó odontosección durante la extracción de los terceros molares retenidos. 


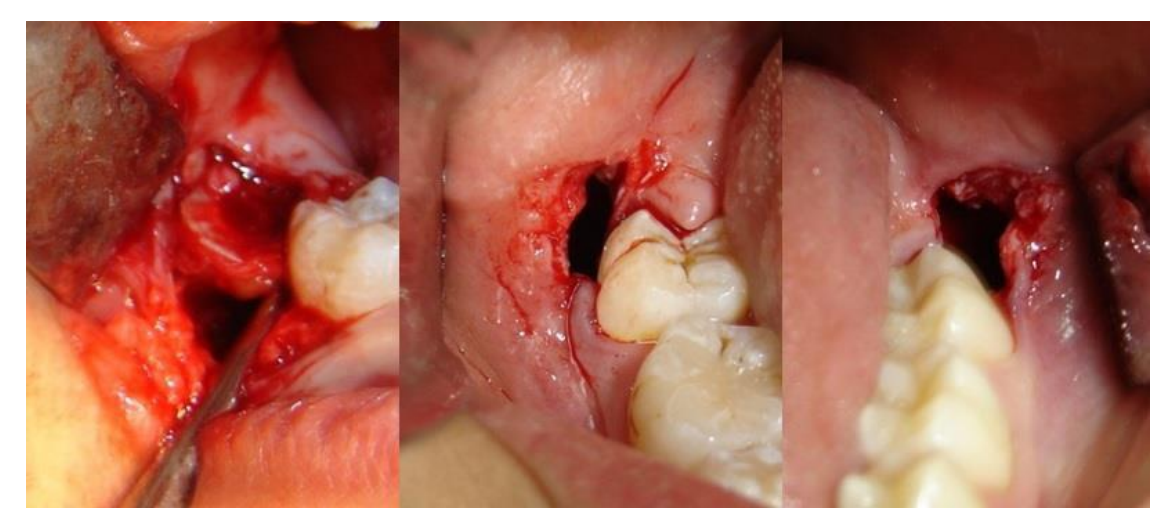

Foto $N^{\circ}$ 4.- Extracción propiamente dicha, Cuidados de la cavidad. Lado derecho, Cuidados de la cavidad. Lado izquierdo

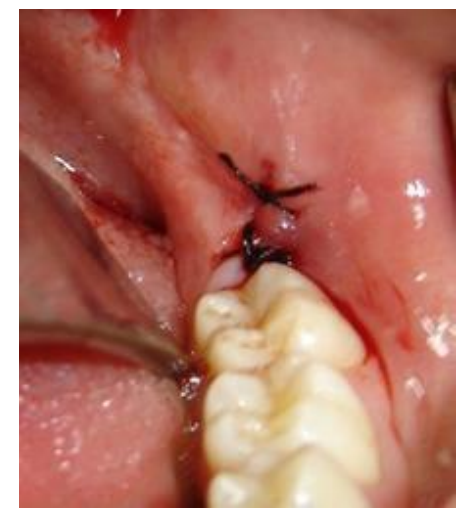

\section{Foto $N^{\circ}$ 5.- Síntesis del colgajo con Seda 3/0 en lado izquierdo}

El cianoacrilato es un líquido, no viscoso, de color violeta, su presentación comercial es un frasco de $5 \mathrm{ml}$. Viene con ámpulas plásticas que se utilizan individualmente con cada paciente, las cuales se llenan con el material mencionado. Se afrontan los bordes de la incisión presionándolos entre sí pero sin tensión, se limpia la zona con torundas de gasa para detener el sangrado, luego se aplica el cianoacrilato en una cantidad de $0.1 \mathrm{ml}$ que corresponde a 3 o 4 gotas en una capa muy fina del mismo, deslizando el cuello de la ámpula plástica sobre los bordes de la incisión. Se aplica el pegamento en superficie y no en la pared cruenta de la herida, ya que actuaría de cuerpo extraño y 
haría de barrera para el proceso de curación. Los excesos del material provocan la formación de una capa de polímero que se desprende fácilmente por roce mecánico. Se mantiene la herida unida por 1 a 2 minutos. $(10,5)$

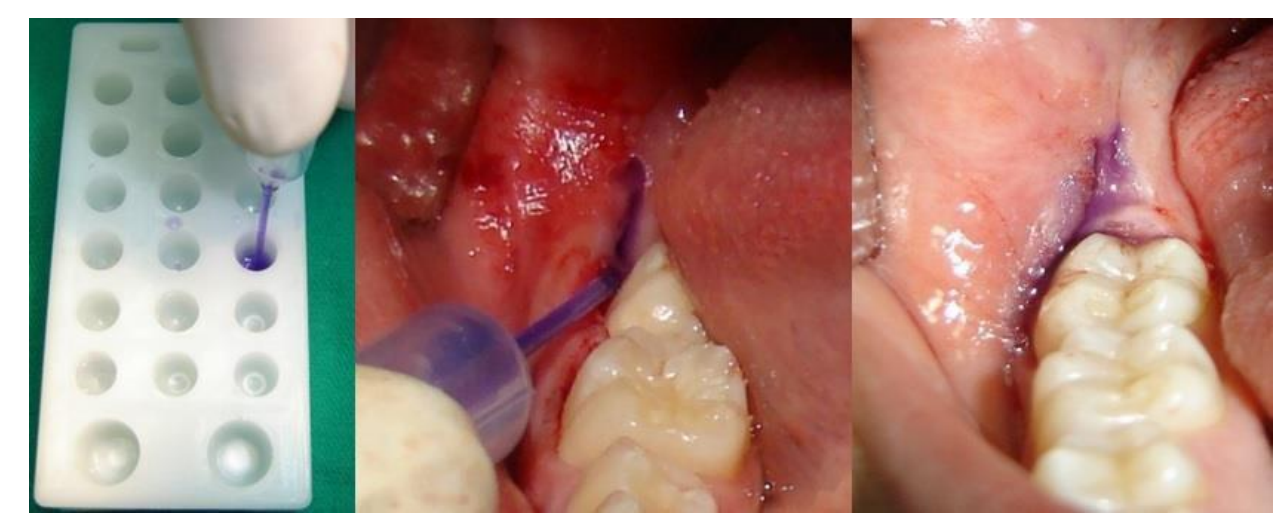

Foto $N^{\circ}$ 6.- Carga del Cianoacrilato en la pipeta, Síntesis del colgajo con Cianoacrilato, Síntesis del colgajo con Cianoacrilato en lado derecho

En esta investigación se evaluaron cada una de variables para darles valores numéricos y se describieron para poder analizarlos individualmente; se observaron los resultados de la utilización de la sutura adhesiva con cianoacrilato y de la sutura convencional con seda $3 / 0$ en cada paciente y se compararon los resultados y los datos para sintetizar las conclusiones y recomendaciones que arrojó la investigación. 
Estudio comparativo entre el uso de la Seda 3/0 y la síntesis adhesiva con Cianoacrilato en cirugía de terceros molares retenidos

Primer chequeo postoperatorio.

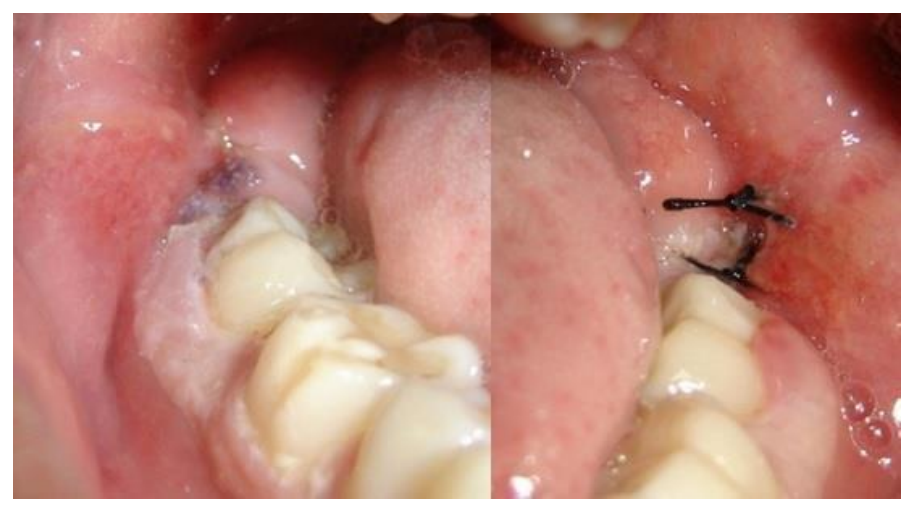

Foto $N^{\circ}$ 7.- Segundo chequeo lado derecho. Cianoacrilato, Segundo chequeo lado izquierdo. Seda 3/0.

\section{Tercer chequeo postoperatorio.}

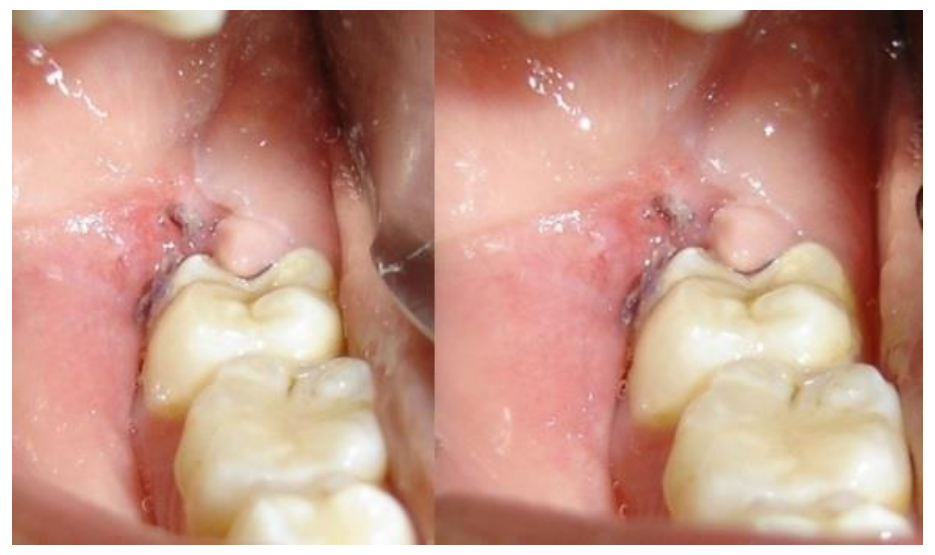

Foto $\mathbf{N}^{\circ}$ 8.- Tercer chequeo lado derecho. Cianoacrilato, Sin presencia de dehiscencia al estirar el carrillo 
Estudio comparativo entre el uso de la Seda 3/0 y la síntesis adhesiva con Cianoacrilato en cirugía de terceros

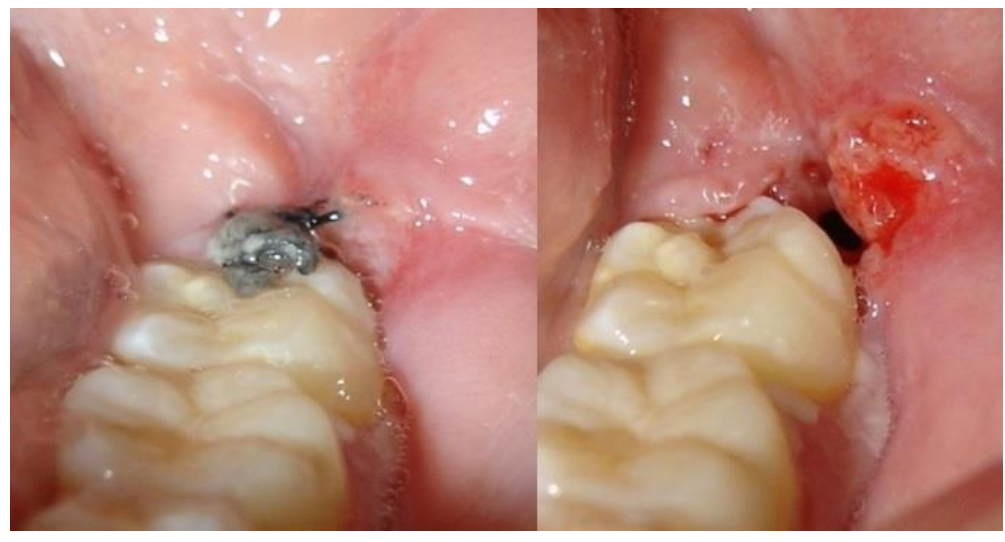

Foto $\mathrm{N}^{\circ}$ 9.- Tercer chequeo lado izquierdo. Seda 3/0, Dehiscencia al retiro de puntos

\section{Resultados.}

En el primer control con Cianoacrilato en relación a la placa bacteriana, el $77.14 \%$ de los pacientes presentaron Tipo 0, el 14.29\% Tipo 1 y el $8.57 \%$ Tipo 2. En el segundo control con Cianoacrilato se mantienen casi los mismos valores del primero en relación a la presencia de placa bacteriana en la zona, aumentando al 17.14\% Tipo 1 y disminuyendo ligeramente al 5.71\% Tipo 2. Durante el tercer control se observan exactamente los mismos valores con respecto al segundo. (Gráficos $N^{\circ} 1,2$ y 3 ) 
Estudio comparativo entre el uso de la Seda 3/0 y la síntesis adhesiva con Cianoacrilato en cirugía de terceros molares retenidos

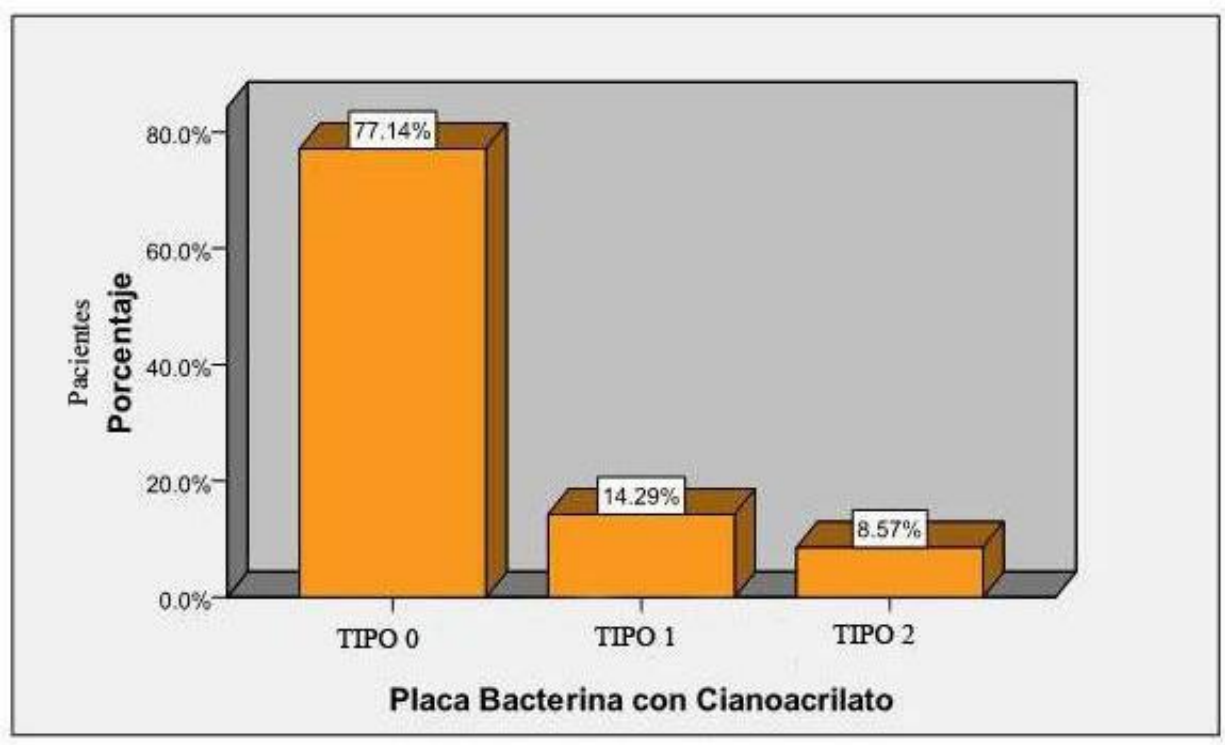

Gráfico $N^{\circ}$ 1.- En el primer control con Cianoacrilato con respecto a la placa bacteriana, el 77.14\% de los pacientes presentaron Tipo 0, el 14.29\% Tipo 1 molar y el $8.57 \%$ Tipo 2

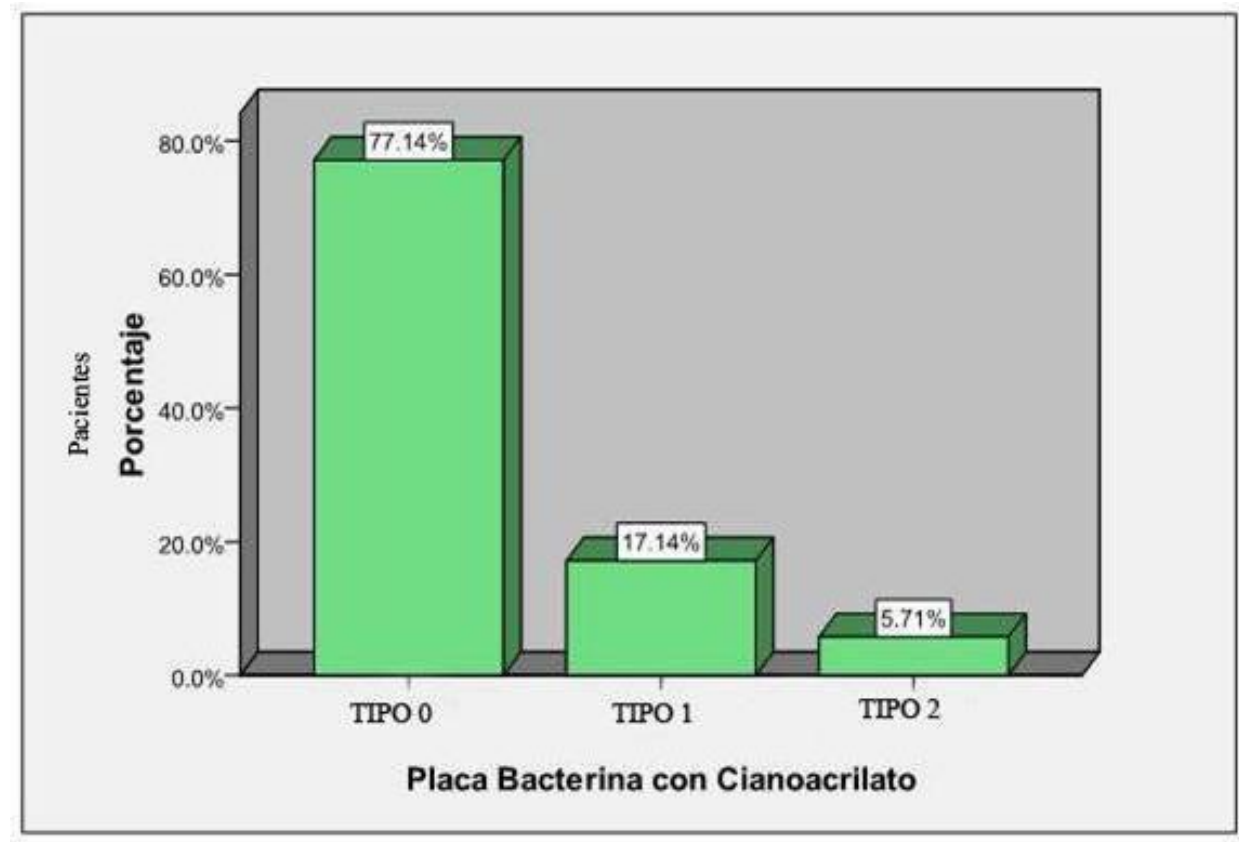

Gráfico $N^{\circ}$ 2.- En el segundo control con Cianoacrilato se mantienen casi los mismos valores del primer chequeo en relación a la presencia de placa bacteriana en la zona, disminuyendo ligeramente al $5.71 \%$ el Tipo 2 y aumentando al 17.14\% los Tipo 1 
Estudio comparativo entre el uso de la Seda 3/0 y la síntesis adhesiva con Cianoacrilato en cirugía de terceros molares retenidos

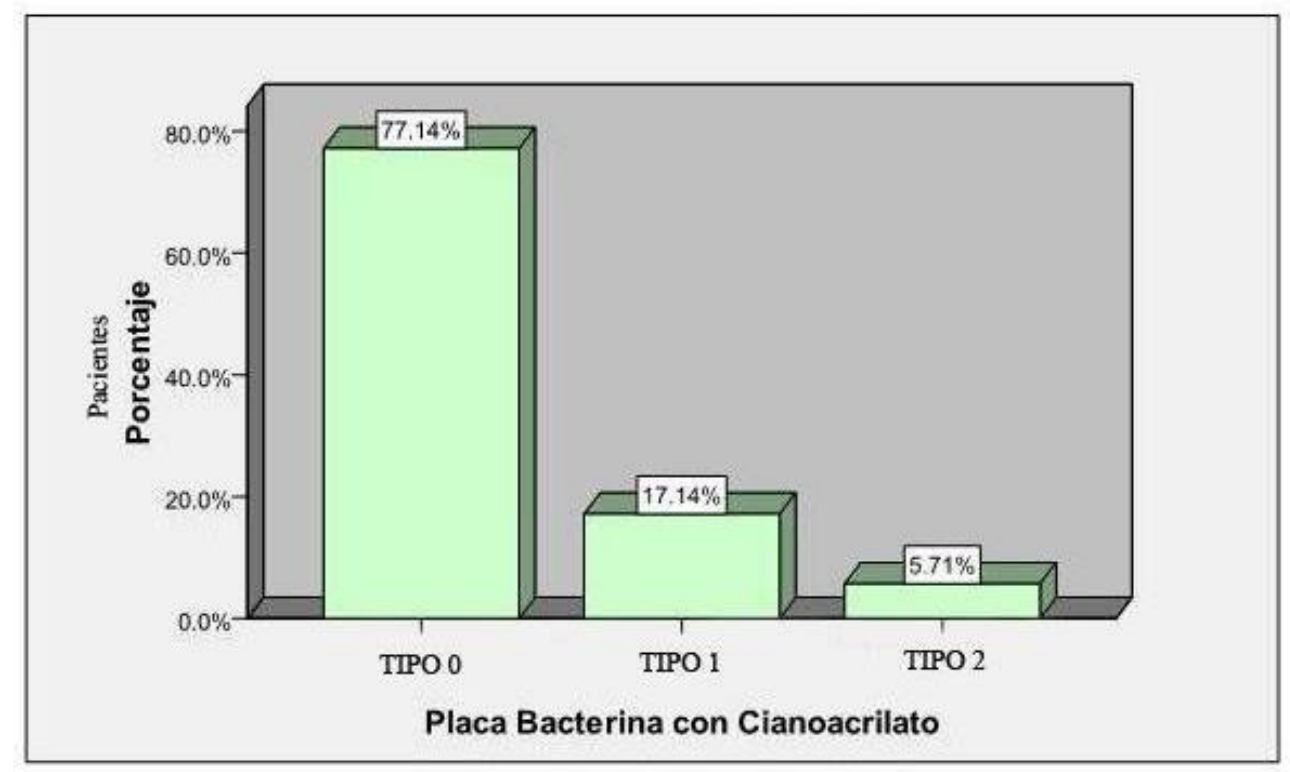

\section{Gráfico $N^{\circ}$ 3.- Durante el tercer control con Cianoacrilato con respecto a la placa bacteriana se ven exactamente los mismos valores con respecto al segundo chequeo}

El primer control de la Seda 3/0 con respecto a la placa bacteriana, se observa que el $22.86 \%$ presentaron Tipo 0, un 54.29\% Tipo 1, el 14.29\% Tipo 2, y el 8.57\% Tipo 3. Durante el segundo control de la seda con respecto a la presencia de placa bacteriana en la zona se observa que disminuyen los pacientes que presentaron Tipo 0 al $2.86 \%$, aumentan a $71.43 \%$ los de Tipo 1 , a 17.14\% Tipo 2 y se mantiene la misma cantidad en el Tipo 3. En el tercer control se mantiene el Tipo 0, disminuyen al 62.86\% Tipo 1 y aumenta al 20\% Tipo 2, así como al $14.29 \%$ Tipo 3.

(Gráficos $\left.N^{\circ} 4,5,6\right)$ 
Estudio comparativo entre el uso de la Seda 3/0 y la síntesis adhesiva con Cianoacrilato en cirugía de terceros molares retenidos

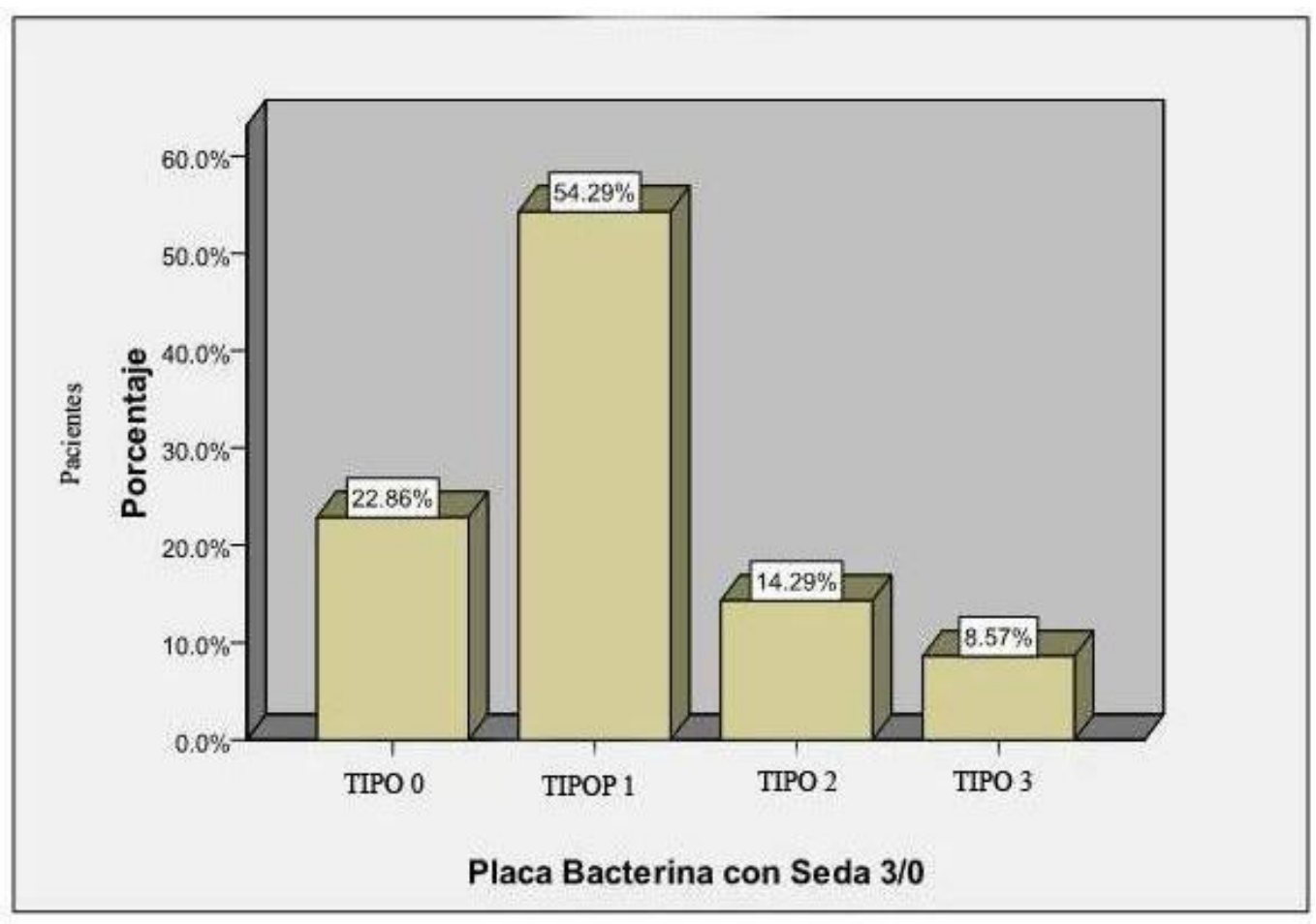

Gráfico $N^{\circ}$ 4.- El primer control de la Seda 3/0 con respecto a la placa bacteriana se observa que el 22.86\% presentaron Tipo 0, un 54.29\% Tipo 1, el 14.29\% fueron Tipo 2, y el 8.57\% Tipo 3

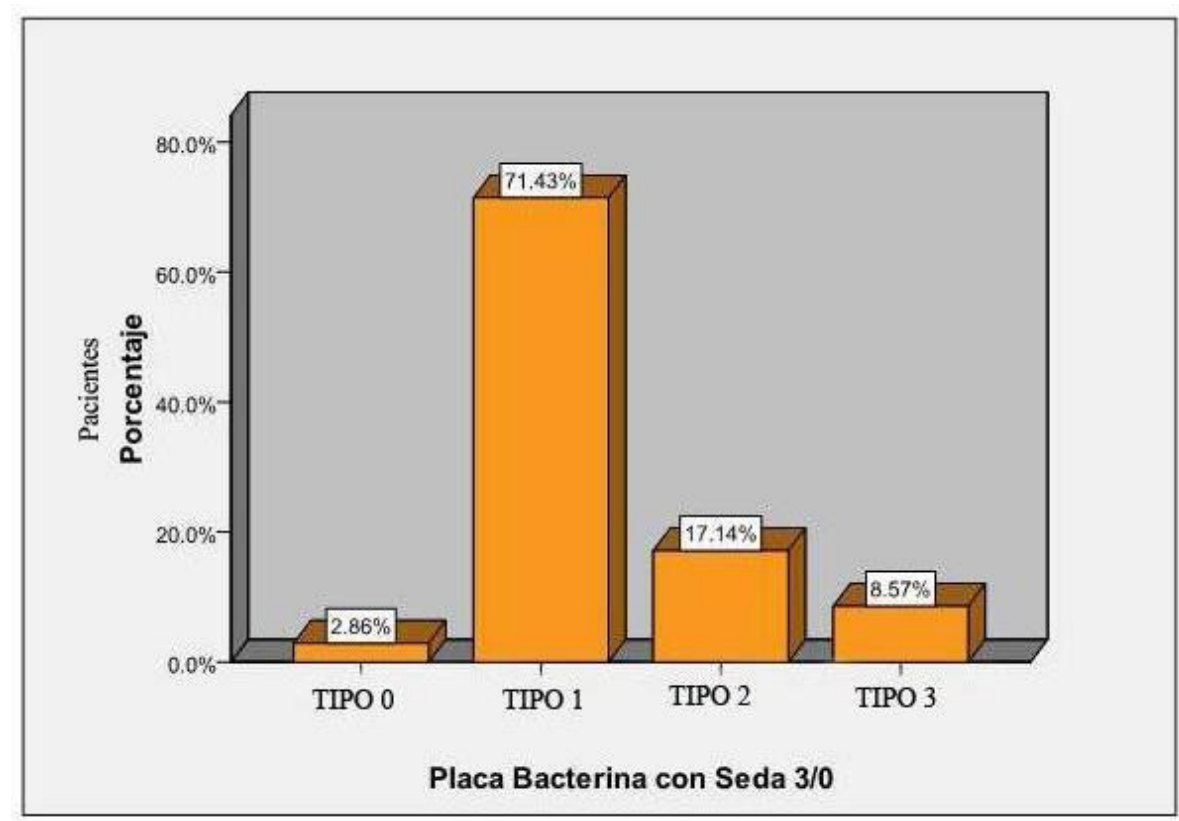

Gráfico $N^{\circ}$ 5.- Durante el segundo control de la seda con respecto a la presencia de placa bacteriana en la zona se observa que disminuye el Tipo 0 al 2.86\%, aumenta el Tipo 1 a $71.43 \%$, Tipo 2 a 17.14\% y se mantiene la misma cantidad en el Tipo 3 
Estudio comparativo entre el uso de la Seda 3/0 y la síntesis adhesiva con Cianoacrilato en cirugía de terceros molares retenidos

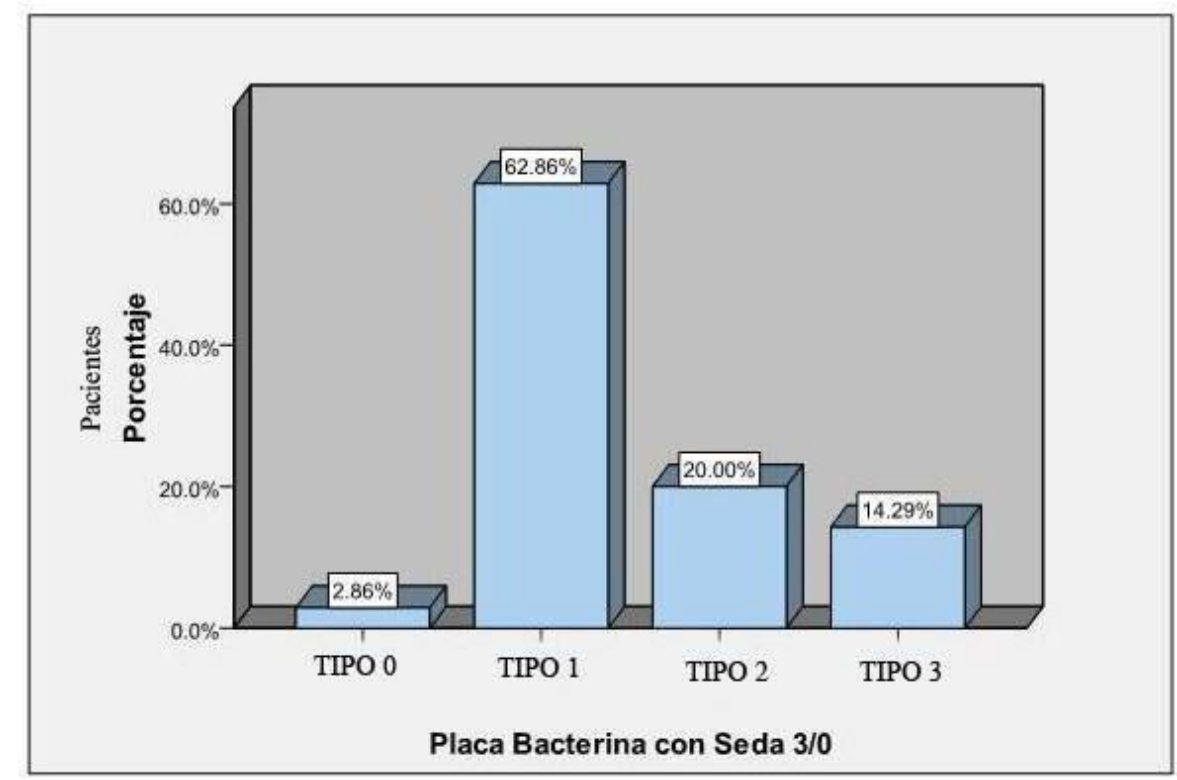

Gráfico $N^{\circ}$ 6.- En el tercer control se mantiene el Tipo 0, disminuyen al 62.86\% Tipo 1 y aumenta al 20\% el Tipo 2, así como al 14.29\% el Tipo 3

El primer control con respecto a la presencia de inflamación en la zona de la operación, con el cianoacrilato se tiene un $34.29 \%$ de pacientes que no la presentaron y un $65.71 \%$ que presentaron una inflamación leve. Durante el segundo control con cianoacrilato se vio que el $60 \%$ de los pacientes no presentan inflamación y el $40 \%$ es leve. En el tercer chequeo con cianoacrilato respecto a la inflamación disminuye la cantidad de pacientes que no la presentan al $94.29 \%$, teniendo solo una leve inflamación el $5.71 \%$ de los pacientes. La inflamación moderada e intensa (2 y 3) no se presentó en ningún caso. ( Gráficos $\left.N^{\circ} 7,8,9\right)$ 
Estudio comparativo entre el uso de la Seda 3/0 y la síntesis adhesiva con Cianoacrilato en cirugía de terceros molares retenidos

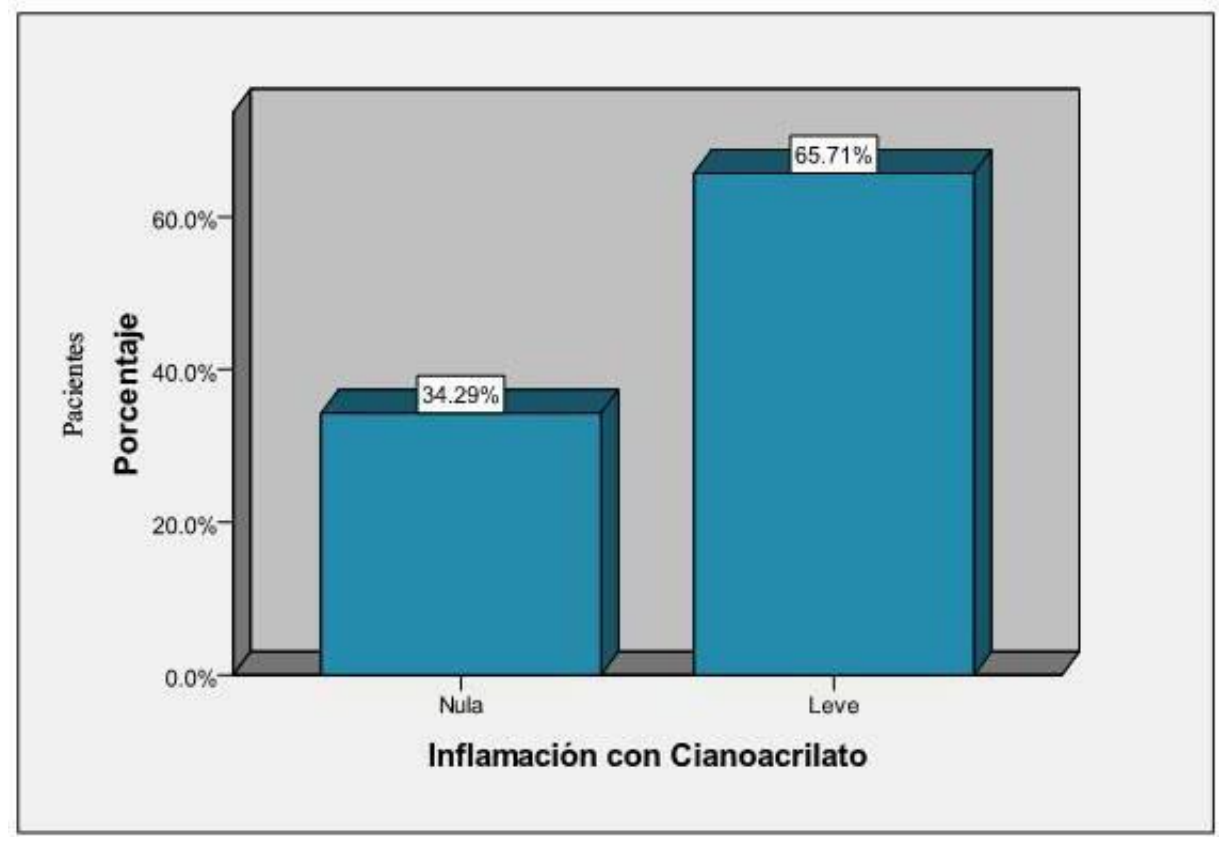

Gráfico $N^{\circ}$ 7.- El primer control con respecto a la presencia de inflamación en la zona de la operación, con el cianoacrilato se tiene un $34.29 \%$ de pacientes que no la presentaron y un $65.71 \%$ que presentaron una inflamación leve

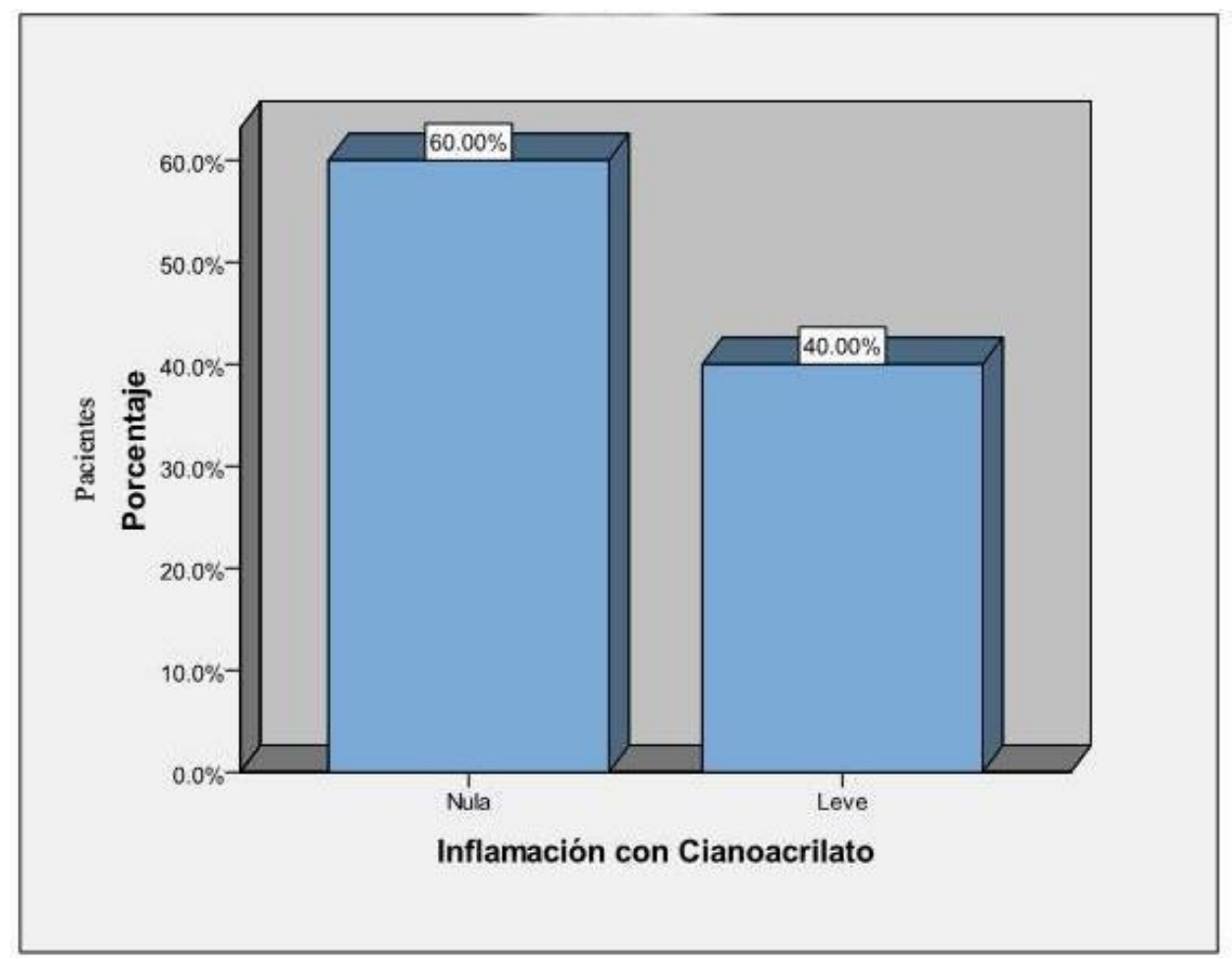

Gráfico $N^{\circ}$ 8.- Durante el segundo control con cianoacrilato se vio que el $60 \%$ de los pacientes no presentan inflamación y el $40 \%$ es leve. 
Estudio comparativo entre el uso de la Seda 3/0 y la síntesis adhesiva con Cianoacrilato en cirugía de terceros molares retenidos

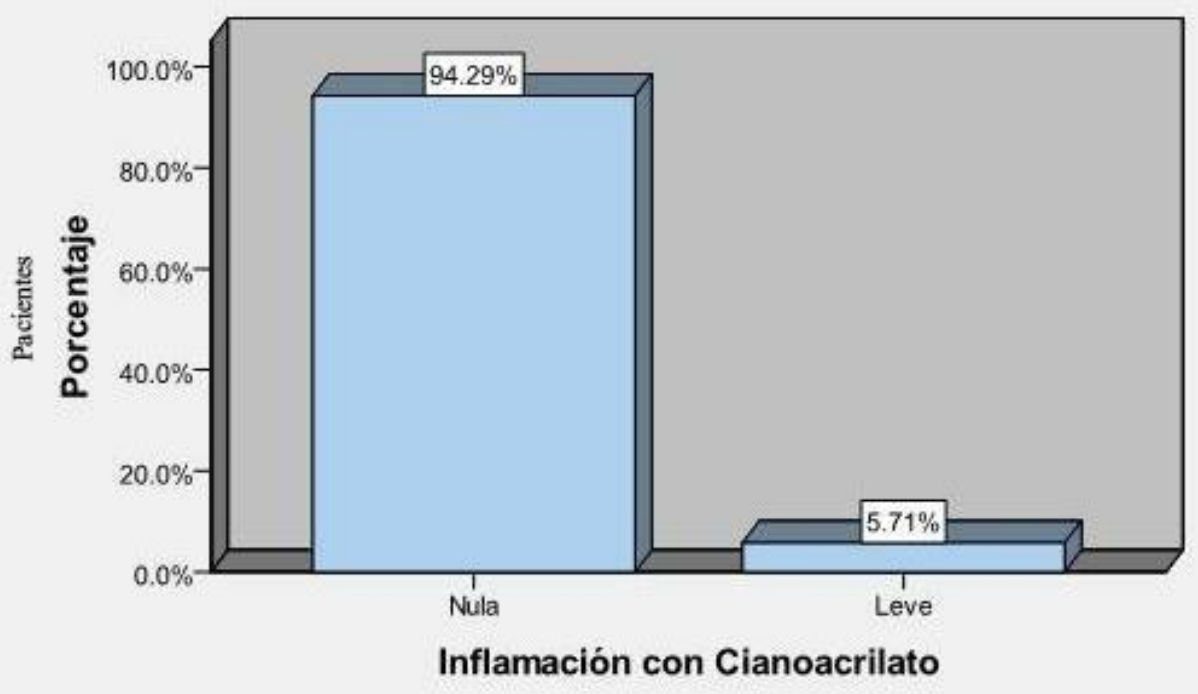

Gráfico $N^{\circ}$ 9.- En el tercer control con cianoacrilato respecto a la inflamación disminuye la cantidad de pacientes que no la presentan al 94.29\%, teniendo solo una leve inflamación el $5.71 \%$ de los pacientes.

En el primer control con la seda 3/0, el 2.86\% de los pacientes no presentaron inflamación y el 97.14\% presentaron una leve inflamación

Durante el segundo control aumentan los pacientes que no presentan inflamación al $22.86 \%$ y aquellos que presentan una leve inflación lo hicieron en un 77.14\%

En el tercer control con la seda 3/0 con respecto a la inflamación el $48.57 \%$ de los pacientes no la presentaron mientras que aquellos que tuvieron una leve inflamación disminuyó al 51.43\%. La inflamación moderada e intensa (2 y 3) no se presentó en ningún caso. (Gráficos $\left.N^{\circ} 10,11,12\right)$ 
Estudio comparativo entre el uso de la Seda 3/0 y la síntesis adhesiva con Cianoacrilato en cirugía de terceros molares retenidos

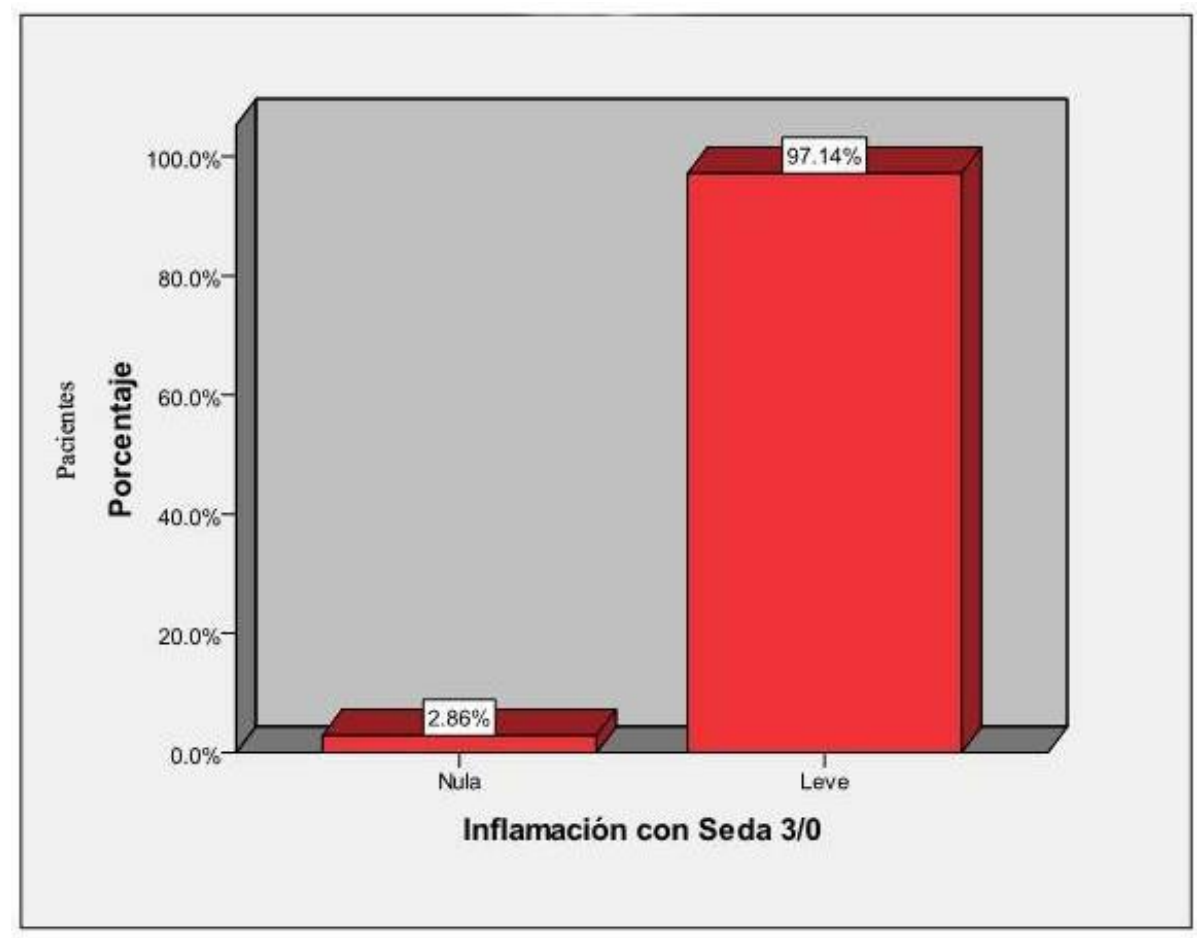

Gráfico $N^{\circ}$ 10.- En el primer control con la seda 3/0, el $2.86 \%$ de los pacientes no presentaron inflamación y el $97.14 \%$ presentaron una leve inflamación

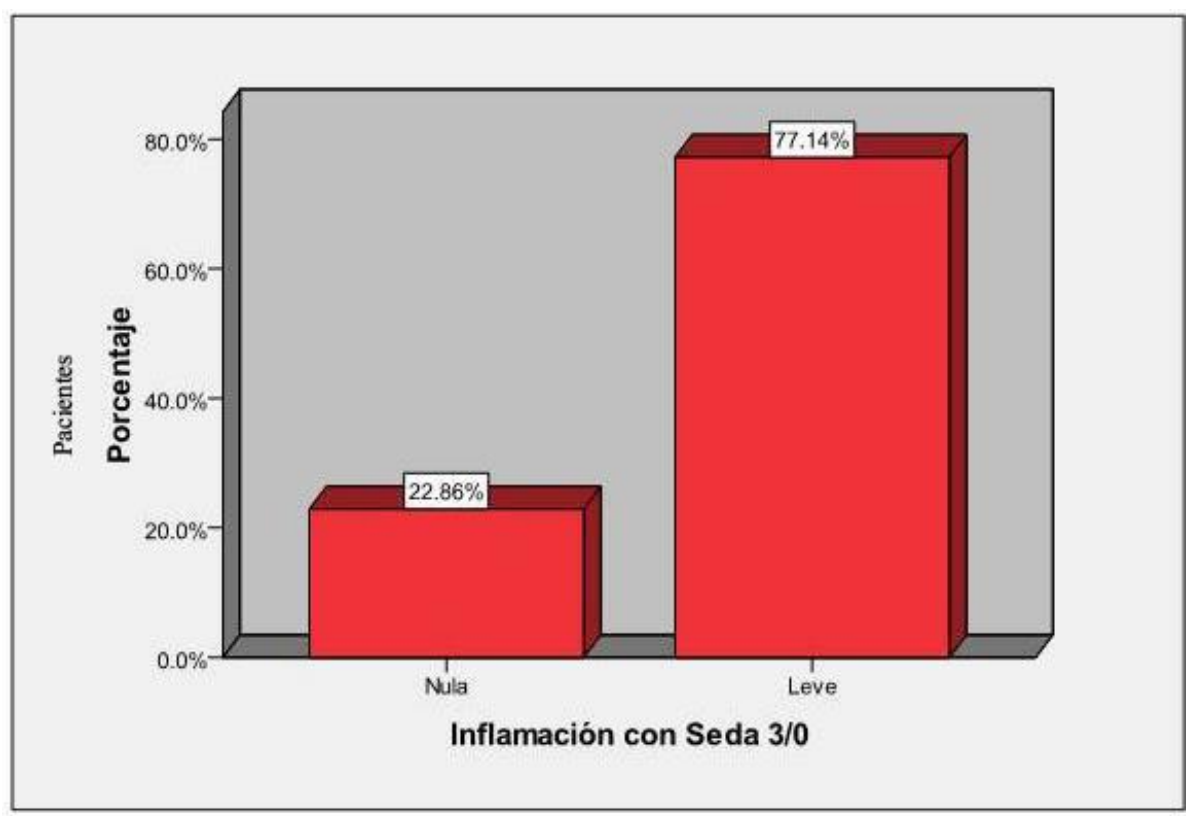

Gráfico $N^{\circ}$ 11.- Durante el segundo control aumentan los pacientes que no presentan inflamación al $22.86 \%$ y aquellos que presentan una leve inflación lo hicieron en un $77.14 \%$ 
Estudio comparativo entre el uso de la Seda 3/0 y la síntesis adhesiva con Cianoacrilato en cirugía de terceros molares retenidos

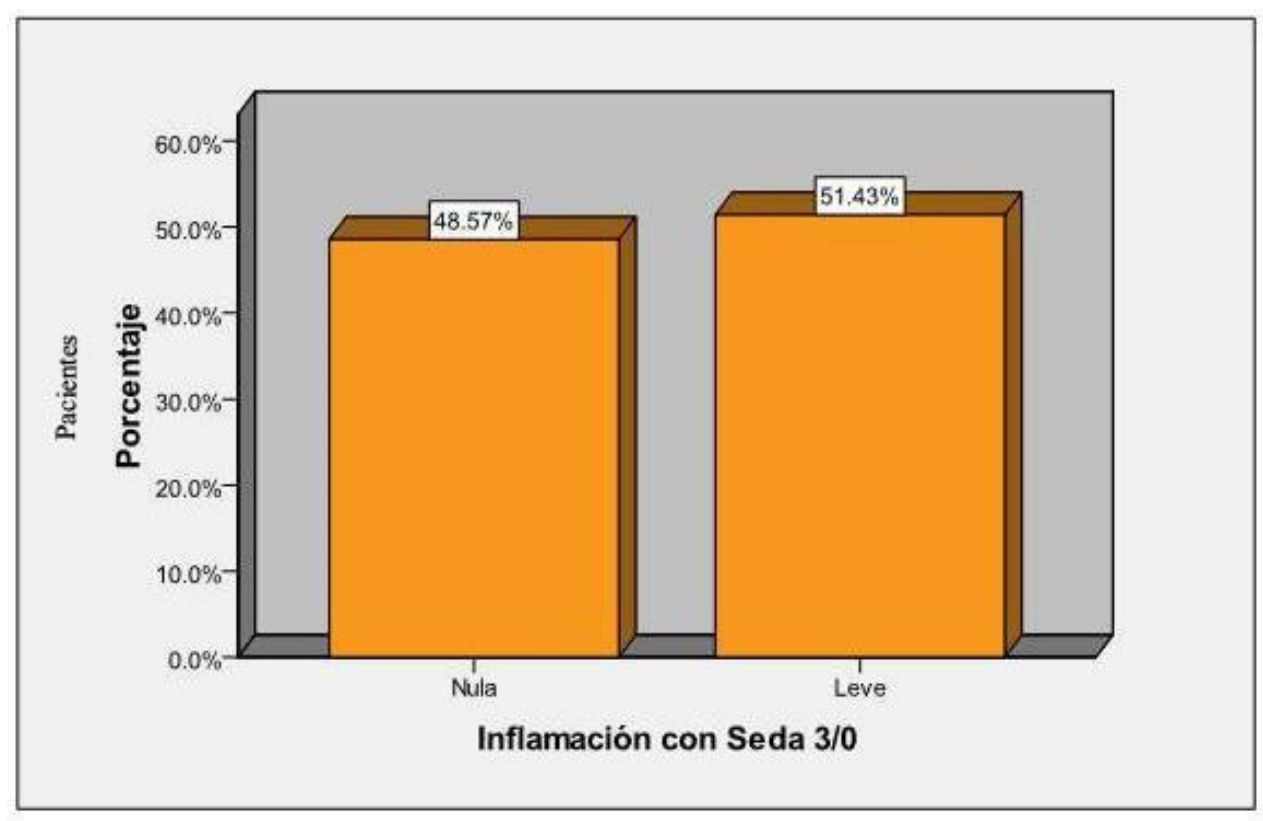

Gráfico $N^{\circ}$ 12.- En el tercer control con la seda 3/0 con respecto a la inflamación el $48.57 \%$ de los pacientes no la presentaron mientras que aquellos que tuvieron una leve inflamación disminuyó al 51.43\%

El primer control con cianoacrilato para ver la dehiscencia el $88.57 \%$ de los pacientes no la presentaron, el $8.57 \%$ tuvieron una leve y el $2.86 \%$ moderada

En el segundo control para observar la dehiscencia con cianoacrilato disminuyen aquellos que no la presentan al $86.86 \%$ y aumentan a una dehiscencia leve el $14.29 \%$

En el tercer control con cianoacrilato, la dehiscencia leve aumenta al $25.71 \%$ mientras que el 71.43\% de los pacientes no la presentan (Gráficos $\left.N^{\circ} \mathbf{1 3}, \mathbf{1 4}, \mathbf{1 5}\right)$. 
Estudio comparativo entre el uso de la Seda 3/0 y la síntesis adhesiva con Cianoacrilato en cirugía de terceros molares retenidos

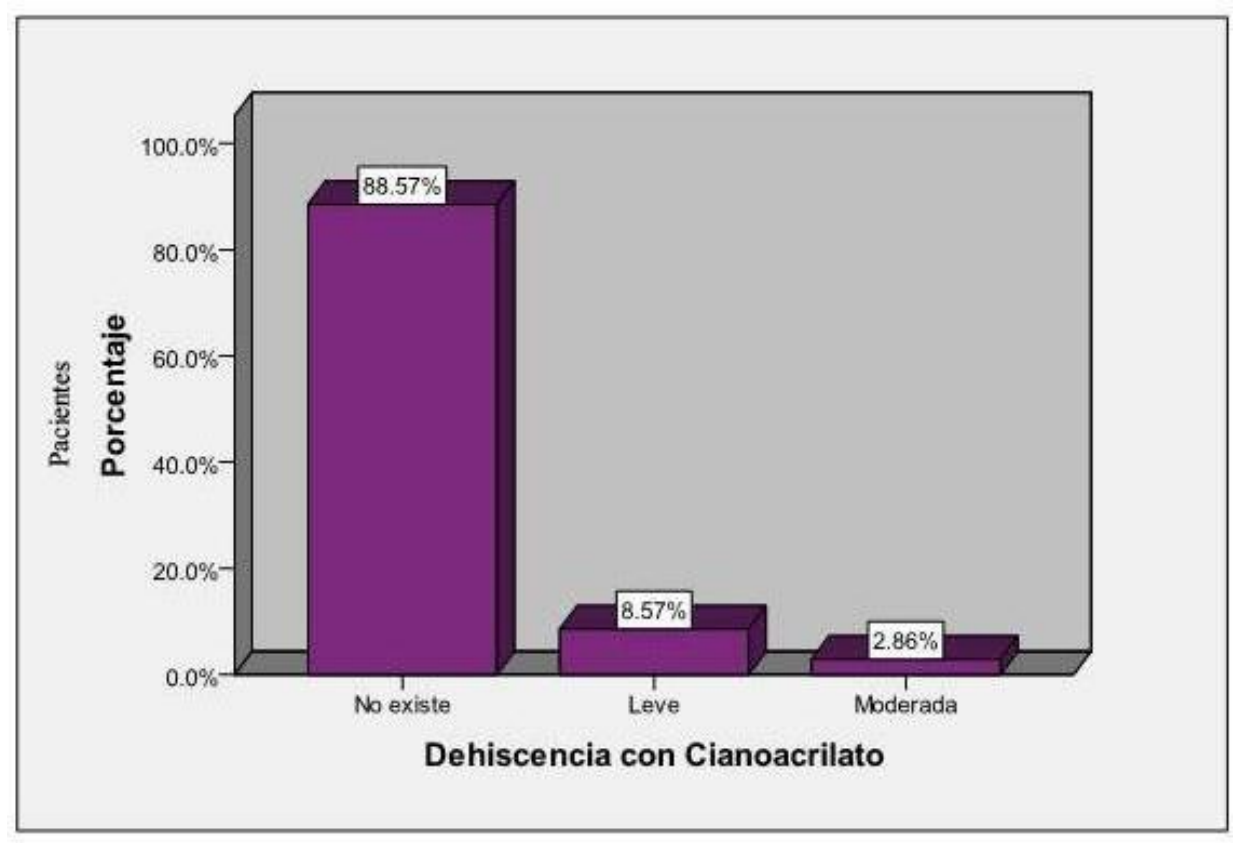

Gráfico $N^{\circ}$ 13.- El primer control con cianoacrilato para ver la dehiscencia el $88.57 \%$ de los pacientes no la presentaron, el $8.57 \%$ tuvieron una leve y el $2.86 \%$ moderada

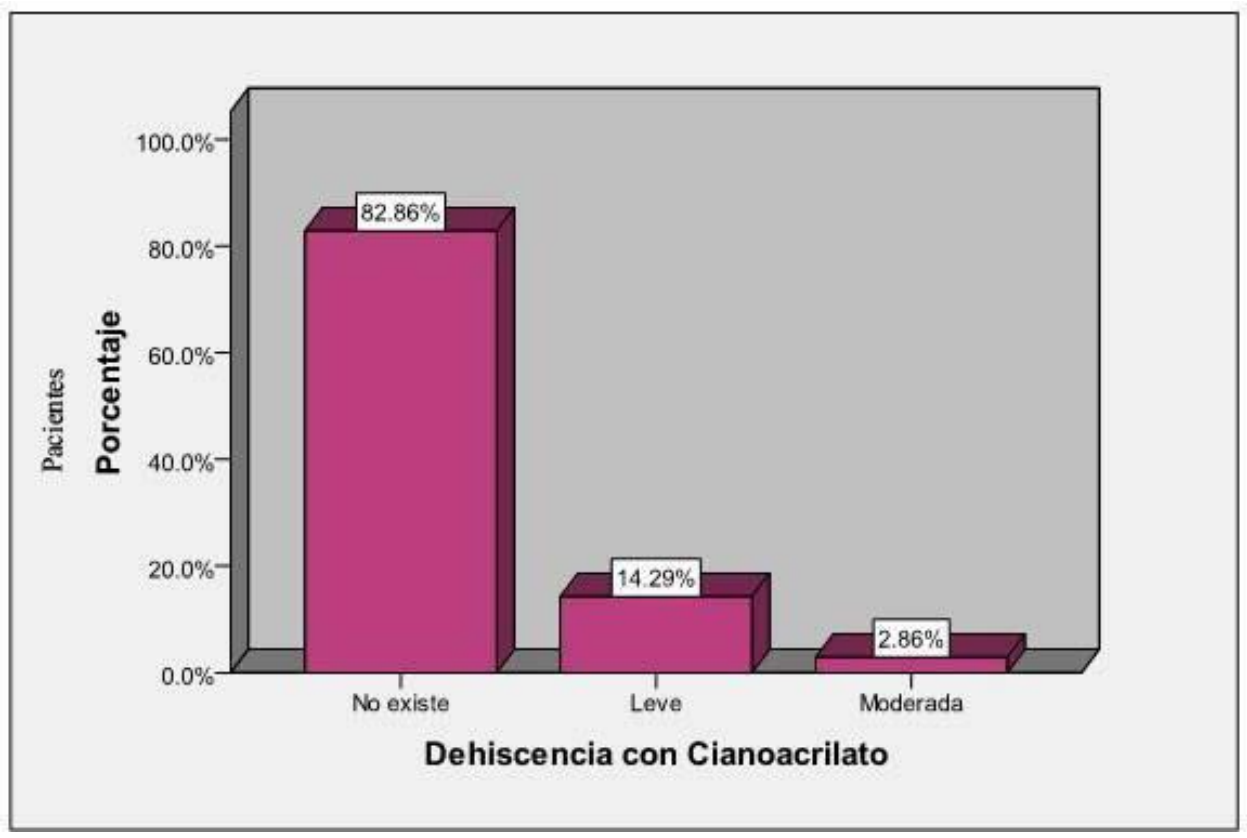

Gráfico $N^{\circ}$ 14.- En el segundo control para observar la dehiscencia con cianoacrilato disminuyen aquellos que no la presentan al $86.86 \%$ y aumentan a una dehiscencia leve el $14.29 \%$ 
Estudio comparativo entre el uso de la Seda 3/0 y la síntesis adhesiva con Cianoacrilato en cirugía de terceros molares retenidos

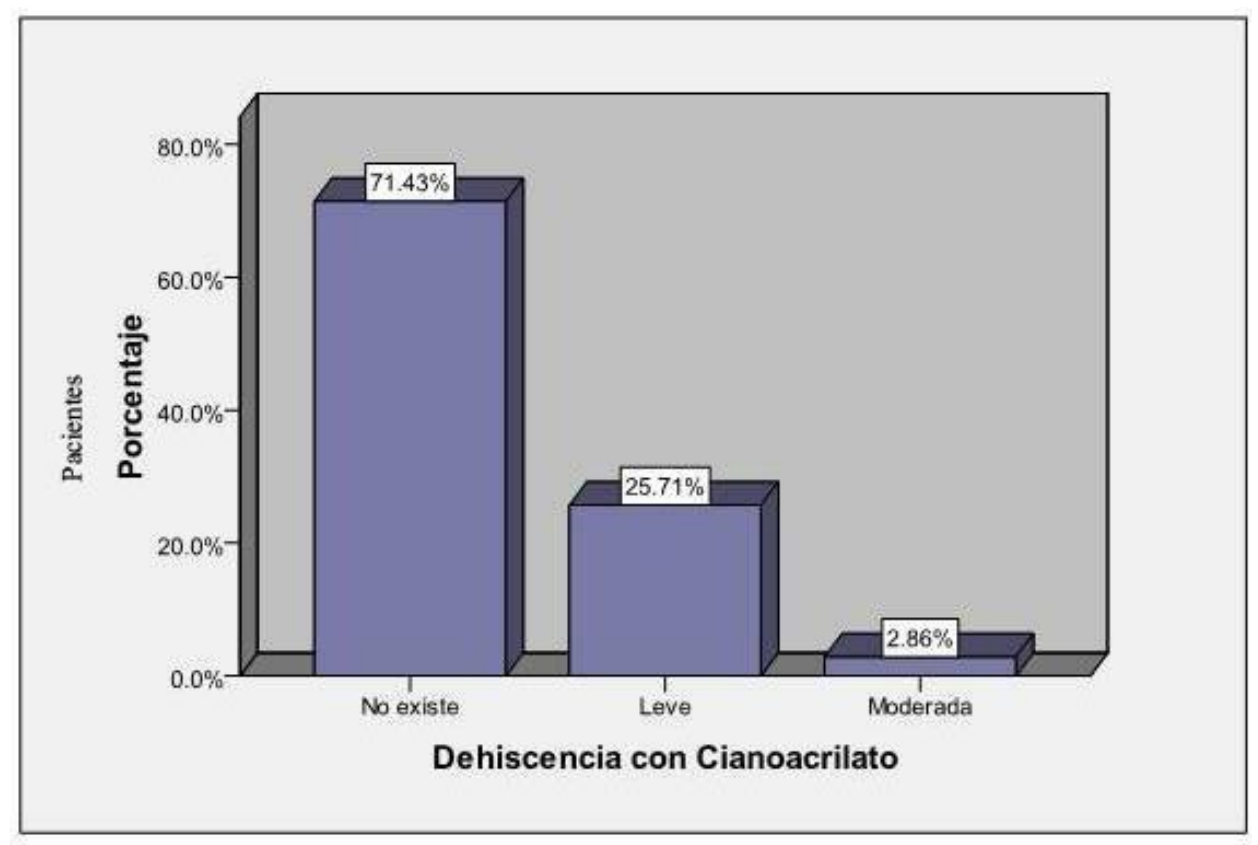

Gráfico $N^{\circ}$ 15.- En el tercer control con cianoacrilato, la dehiscencia leve aumenta al $25.71 \%$ mientras que el $71.43 \%$ de los pacientes no la presentan

En el primer control con seda $3 / 0$ el $25.71 \%$ de los pacientes no presentan dehiscencia, el $42.86 \%$ presentan una dehiscencia leve y el $31.43 \%$ una moderada

En el segundo control con seda 3/0 aumenta al $85.71 \%$ los pacientes presentan una dehiscencia moderada, el $5.71 \%$ leve y solo el $8.57 \%$ de ellos no la presentan

En el tercer control con seda $3 / 0$ solo el $2.86 \%$ de los pacientes no presentan dehiscencia mientras el 97.14\% presentan una dehiscencia moderada (Gráficos $\left.N^{\circ} 16,17,18\right)$ 
Estudio comparativo entre el uso de la Seda 3/0 y la síntesis adhesiva con Cianoacrilato en cirugía de terceros molares retenidos

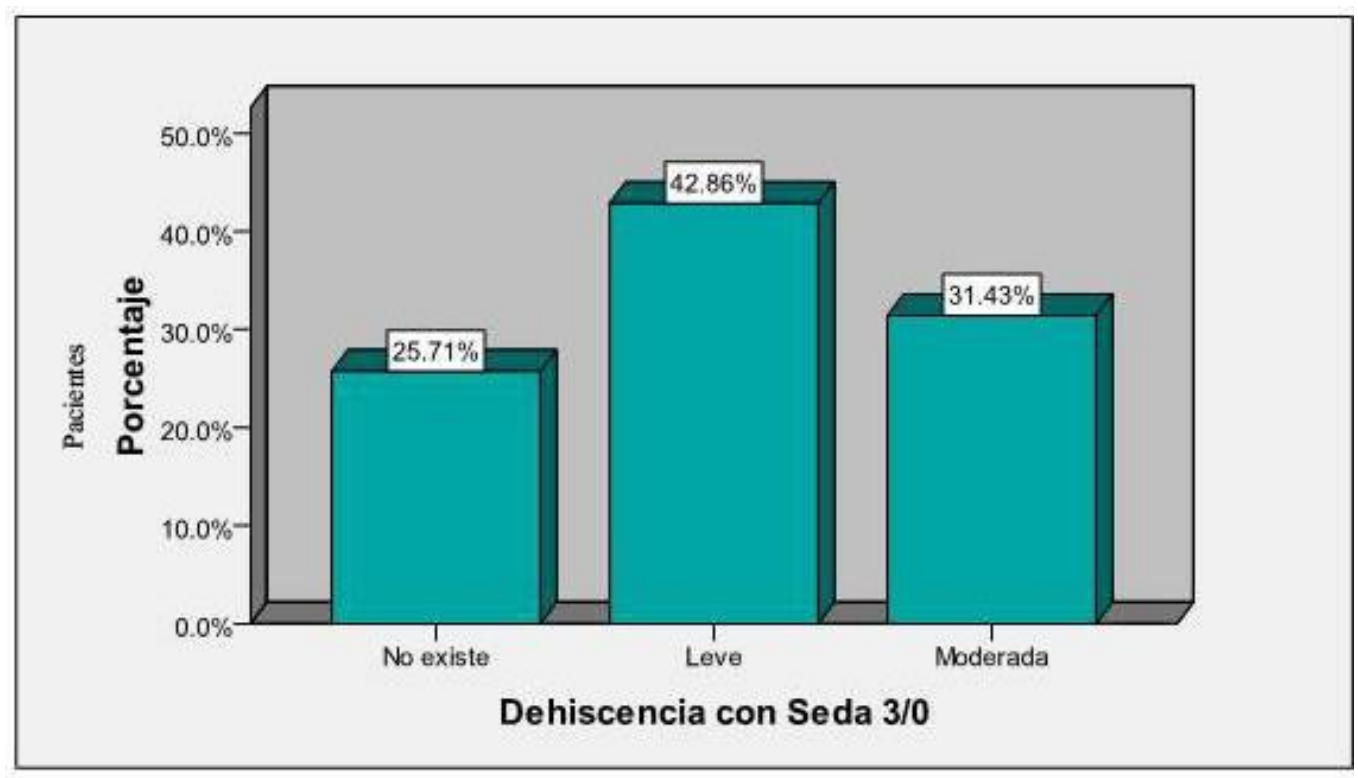

Gráfico $N^{\circ}$ 16. - En el primer control con seda $3 / 0$ el $25.71 \%$ de los pacientes no presentan dehiscencia, el $42.86 \%$ presentan una dehiscencia leve y el $31.43 \%$ una moderada

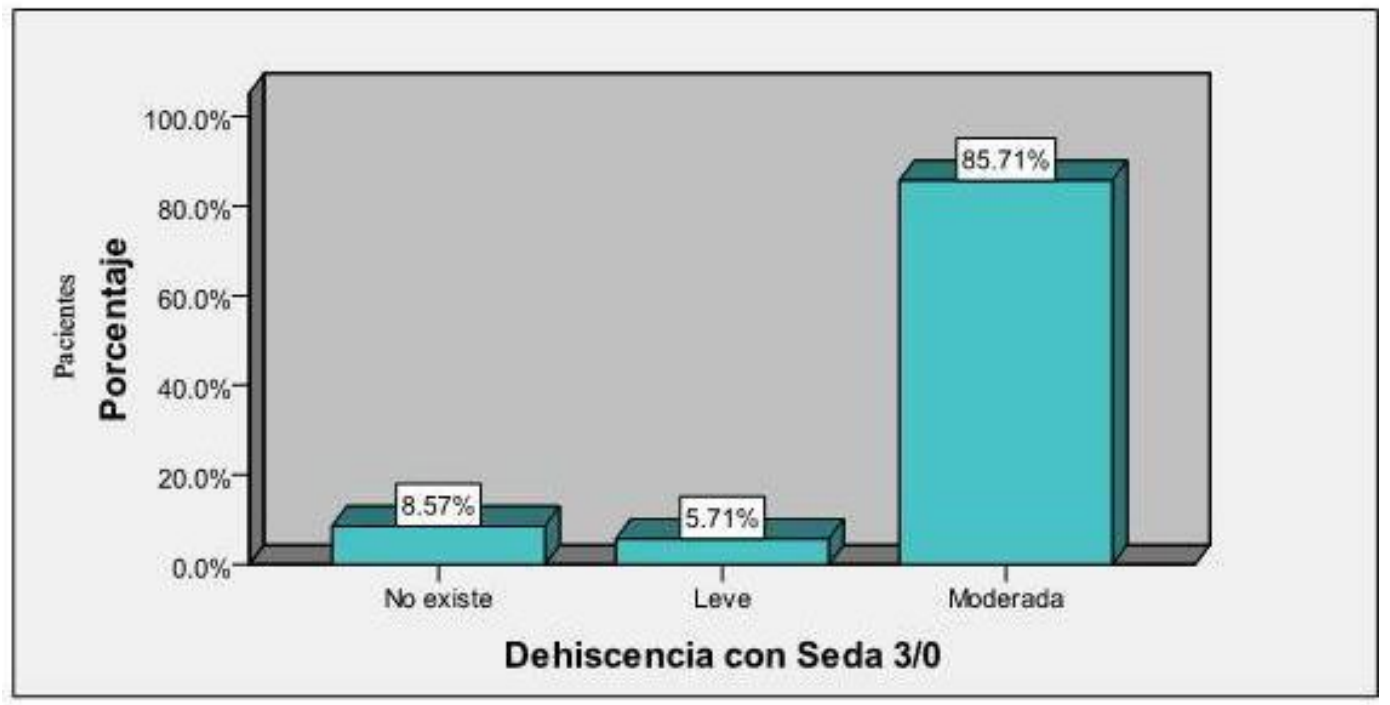

Gráfico $N^{\circ}$ 17.- En el segundo control con seda 3/0 aumenta al $85.71 \%$ los pacientes presentan una dehiscencia moderada, el $5.71 \%$ leve y solo el $8.57 \%$ de ellos no la presentan 
Estudio comparativo entre el uso de la Seda 3/0 y la síntesis adhesiva con Cianoacrilato en cirugía de terceros molares retenidos

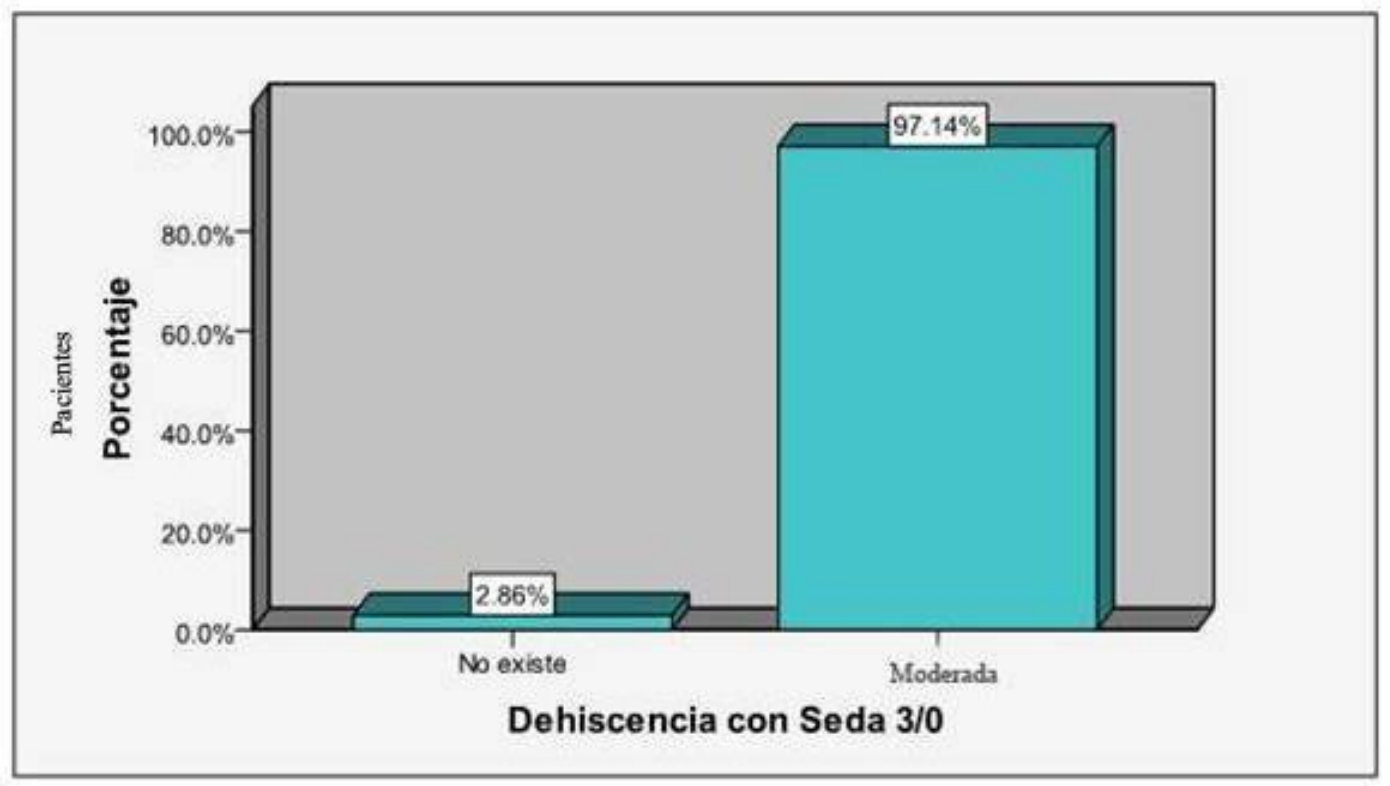

\section{Gráfico $N^{\circ} 18 .-$ En el tercer control con seda 3/0 solo el $2.86 \%$ de los pacientes no presentan dehiscencia mientras el $97.14 \%$ presentan una dehiscencia moderada}

Con los dos materiales no se presentó infección en ninguno de los controles, puesto que los pacientes no tuvieron complicaciones durante el proceso postquirúrgico y todos ellos han cumplido a cabalidad las indicaciones y cuidados postoperatorios. (Gráficos $\left.N^{\circ} 19,20\right)$

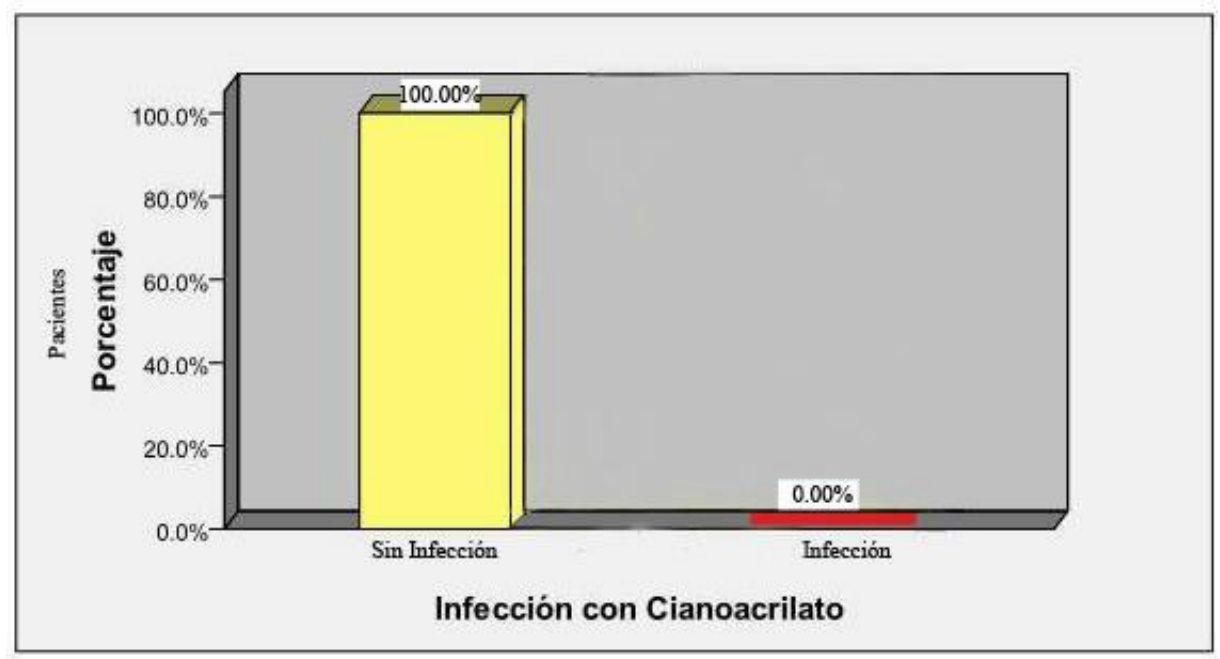

Grafico $N^{\circ}$ 19.- En el primero, segundo y tercer controles posoperatorios que corresponden al tercero, quinto y séptimo días con cianoacrilato el $100 \%$ de los pacientes no presentan infección 


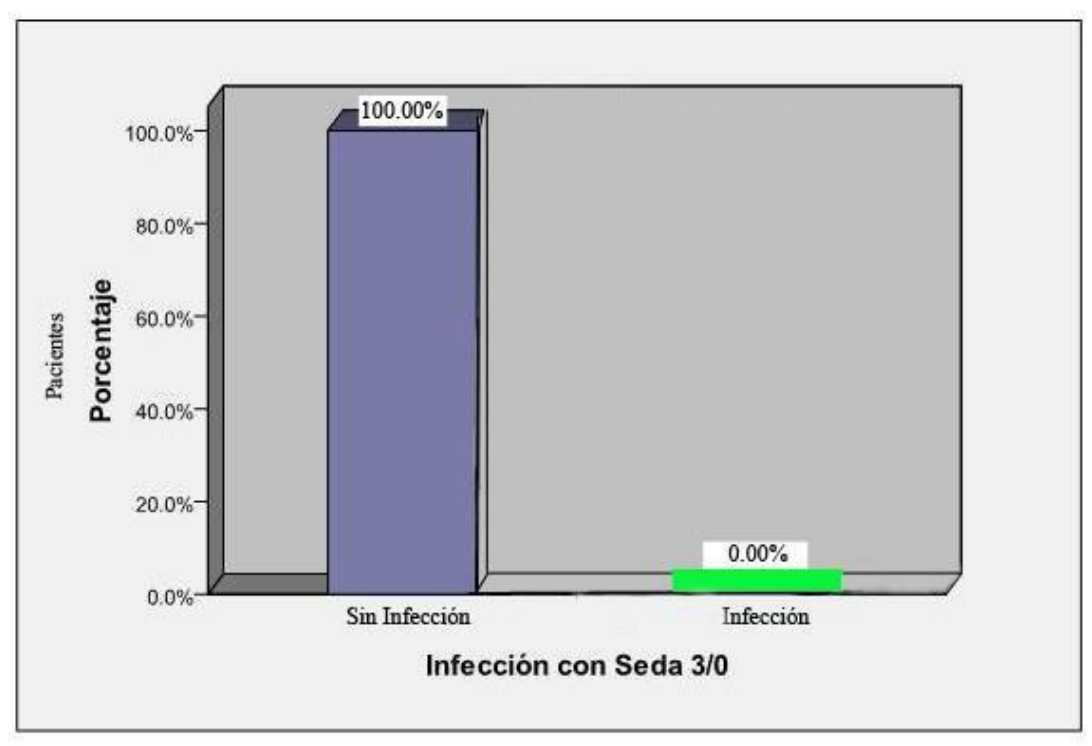

Gráfico $N^{\circ}$ 20.- En el primero, segundo y tercer controles posoperatorios que corresponden al tercero, quinto y séptimo días con seda 3/0, el 100\% de los pacientes no presenta infección

\section{Discusión.}

Observando los resultados obtenidos en éste estudio, el uso de cianoacrilato como medio de afrontamiento de colgajos mucoperiósticos en exodoncia de terceros molares retenidos Mesioangulares, clase II, posición B, básicamente disminuye el tiempo de colocación y no necesita ser removido. En la cavidad bucal como sutura adhesiva ha dado excelentes resultados, se piensa, por lo tanto, que el cianoacrilato es un material óptimo que elimina las posibles complicaciones como la acumulación de placa bacteriana en la zona operada, infección, presencia de inflamación en el área intervenida y la dehiscencia de los bordes de la herida.

La experiencia que reportaron los pacientes con respecto a este material fue satisfactoria. 
El resultado en las últimas investigaciones odontológicas y médicas permiten enfatizar que el cianoacrilato es un material de fácil aplicación, buena tolerancia tisular, tiene efecto hemostático, carece de toxicidad y por su incorporación al organismo no necesita su remoción.

Como resultado de la investigación bibliográfica realizada por el autor antes y después de comenzar a usar el cianoacrilato, en comparación con la síntesis convencional con seda 3/0, surge la variedad de aplicaciones de este material en vivo y los experimentos in vitro, y el gran porcentaje de éxitos logrados con su uso en las diferentes aplicaciones. En Odontología el cianoacrilato ha sido aplicado con diferentes propósitos, como adhesivo tisular, como hemostático, como material de protección pulpar y para el tratamiento de la hiperestesia dentinaria. Si bien no es área del autor opinar sobre las experiencias médicas de las diferentes aplicaciones del cianoacrilato, los resultados obtenidos resaltan las cualidades del mismo como adhesivo tisular, con características biodegradables, que le permiten permanecer en los tejidos hasta su total recuperación.

\section{Conclusiones.}

Tanto el hilo de seda 3/0 como el cianoacrilato son materiales para la síntesis de heridas quirúrgicas, sin embargo se ha demostrado la mayor efectividad del Cianoacrilato sobre colgajos mucoperiósticos en cirugía de terceros molares retenidos mesioangulares, clase II, posición B.

Analizando los procesos de cicatrización de las heridas quirúrgicas se ha verificado que la herida en el lado donde se utilizó el Cianoacrilato, se observa mínima o ninguna acumulación de placa bacteriana. 
La inflamación es menor con el uso del Cianoacrilato, los pacientes refieren menos molestias al respecto

Existe una dehiscencia considerablemente menor en la herida suturada con Cianoacrilato en relación con la seda 3/0, en las cuales, la mayoría de pacientes si la presentaba.

Con ninguno de los materiales utilizados en esta investigación se presentó infección en la zona operada, a pesar de la mayor presencia de placa bacteriana sobre los hilos de sutura de seda 3/0, lo cual indica que la probabilidad de producirse infección el momento de retiro de puntos es casi nula.

La técnica es mucho más sencilla con la sutura adhesiva, además es más cómodo para el paciente puesto que requiere menos tiempo y no necesita retiro de puntos posteriores.

\section{Bibliografía.}

1. Chiapasco M, Romeo E. Rehabilitación implantosoportada en caso complejos Italia: Amolca; 2006.

2. Yepez-Guillen J, Velazco G, Martínez N. Respuesta tisular postexodoncia ante la sutura con técnica convencional y adhesivo tisular (TISUACRYL®): Reporte de un caso. REDOE. 2010 sep; 2(3).

3. Pineda-Mejia M, Salcedo-Moncada D, Palacios-Alva E, Zambrano S, Zeballos W, Ochoa-Tataje J, et al. Influencia del uso de Papacarie en el sellado marginal de obturaciones directas. Odontología Sanmarquina. 2008; 11(2): p. 51-55.

4. Villavicencio J, Piña B. N-butil-cianoacrilato en cirugía periodontal. Revista ADM. 2005 agos; 62(4): p. 148-157.

5. Barroso-Palomino M. Utilización del adhesivo tisular tisuacryl en Estomatología. Revisión bibliográfica. Revista Cubana de Estomatología. 2005 sep; 42(3): p. 1-9.

6. Rodríguez Y, Guerra R, Durán I, Prieto E. Esterilización, estabilización y estudio del carácter antimicrobiano del Tisuacryl. Revista CENIC Ciencias Biológicas. 2006; 37(3): p. 137-141.

7. Mulet-Homs M, Alío J, Sanz J, Sakla H, Bujanda M, Martinez J. Nuevo adhesivo Adal-1®: determinación de su fuerza tensil en la unión de tejido muscular y esclera. ARCH. SOC. ESP. 
OFTALMOL. 2000; 75(1): p. 165-170.

8. Barreras M, Leuman M, Barreras P, Guerra R. Eficacia del Tisuacryl en las intervenciones quirúrgicas periodontales. Revista CENIC Ciencias Biológicas. 2007; 37(3): p. 143-146.

9. Cerquella C, Martínez-Santos C, Moreno-Azcoita M, Fernández-Lobato R, Fernández-Luengas D, Serantes A. Aplicación de Histoacryl® en dermolipectomías y eventraciones. Cirugía Española. 2000 ene; 67(1): p. 119-120.

10. Cañizares-Grupera M, Carral-Novo J, Torre-Rufo J. Recomendaciones para el uso del Adhesivo Hístico Tisuacryl. Rev Cub Med Mil. 2000 abr; 29(1): p. 57-60. 